\title{
A NOTE ON DERIVATIVES OF "CELESTINA"
}

\author{
Hensley C. Woodbridge \\ Southern Illinois University-Carbondale
}

In mid-August 1995 I visited Chile for a period of ten days. It was my good fortune to visit with Antonio Skármeta, one of Chile's outstanding contemporary novelists. He autographed for me a copy of his Match Ball $(=M B)$ (Santiago: Ed. Sudamericana, $3^{\mathrm{a}}$ reimpresión, 1994). In the meantime I had purchased a copy of his Ardiente paciencia $(=A P)$ (Buenos Aires: Ed. Sudamericana, 1985; 1994).

Skármeta uses in the two novels both celestino and celestinaje as the following citations show:

... a pesar de que era un tema celestino ... $(A P, 107)$

Soy tu celestino, tu cabrón y el padrino de tu hijo. ( $A P$ 125)

...que nos había oficiado Forbes en su rol de celestino... $(M B, 150)$

Skármeta would seem to use celestinaje as a synonym for celestino. In his "Notas" to $A P$, there is this entry:

Celestino/Celestinaje: Celestina es un personaje literario, figura central de la obra dramática de F. de Rojas, Tragicomedia de Calixto y Melibea. Por extensión, designa a la persona que arregla los encuentros de dos enamorados. (151)

In the text of $A P$, the word appears thus: "Se trataba de un pequeño acto de celestinaje..." (70). 
I next tried to see if dictionaries of chilenismos dealt with either word. The Academia Superior de Ciencias Pedagógicas de Valparaíso's Diccionario ejemplificado de chilenismos, vol. 2 (Santiago: Ed. Universitaria, 1985) defines celestinaje at page 89 as follows: "Actividad propia del celestino" and gives this citation from Marta Brunet's Montafia adentro (Buenos Aires: Losada, 1953): "La vieja volvía con los huesos, muy sosegadamente, ni buena ni mala en aquel celestinaje" (95). Polí Délano uses the word in his Los mejores cuentos (Santiago: Zig-Zag, 1969) at p. 33: this dictionary provides the following citation from the collection "Servicio telefónico interior: celestinaje legal."

The same dictionary notes that in Chile both celestino and celestina are found and that the dictionary of the Real Academia Española provides data on only celestina. It gives this citation with celestino used as a noun: "Este viejo celestino se le lleva haciéndole propaganda a sus sobrinas." According to this same source, celestino is also given as "panqueque" and is illustrated with this sentence: "me encantan los celestinos rellenos con jamón."

I checked such dictionaries of americanismos as are found in the Southern Illinois University-Carbondale Library with little luck. The Lexicón de colombianismos, $2^{\text {nd }}$ ed. (Bogotá: Banco de la República, 1983), compiled by Mario Alario di Filippo, provides the following:

celestinaje, m. Alcahuetería

celestinear, tr. Alcahuetear

One might assume that these words would appear in slang dictionaries published in Spain. My sample of such dictionaries is too small for the drawing of significant conclusions. Martin Alonso, Enciclopedia del idioma (Madrid: Aguilar, 1958, p. 1,018) notes that the verb celestinear is found in writers of 19 th and 20 th centuries with the meaning of "alcahuetear" and notes its use in Benito Pérez Galdos' Amadeo I and cites "Algo se celestineaba alli..." (Episodios nacionnles [Madrid: Ed. Urbión/Ed. Hernando, 1979]; 10: 4382). While Covarrubias' Tesoro de la lengua castellana o espaniola entry for 'Celestina' is "nombre de una mala vieja, que le dio a la tragicomedia española tan celebrada," the $21^{\text {st }}$ ed. of the Diccionario de la Real Academia Española (1972) shows how associated meanings have come into common usage (celestina ${ }^{1}$ is given as figurative for 'alcahueta'; celestinazgo is the masculine noun for the

${ }^{1}$ I have used the edition of this seventeenth-century work printed in Madrid by Castalia in 1994, in an edition by Felipe C. R. Maldonado and Manuel Camarero (p. 294). 
'acción de celestinear'; celestinear, the verb, is 'ejercer o practicar la función propia de una celestina'; and, finally the adjectival form is given as celestinesco/a and is described as 'perteneciente o relativo a la celestina.'

The verb is not used reflexively in Colombia and Chile according to my data. Others with larger collections of dictionaries from the Spanish-speaking world probably will be able to provide data on other derivatives or uses of celestina, celestino, celestinaje and celestinear. Others with good access to Portuguese materials might see if there are derivatives in that language. The Dicionário da lingua portuguesa elaborado por Antenor Nascentes (1961) defines celestina, a feminine noun, as "alcoviteira" (De Celestina, nome de uma personagem da Tragicomédia de Calixto e Melibéia). The Codil Dicionário prítico (Sao Paulo,1965; I:313) provides the same meaning for celestina, but labels it a figurative meaning.

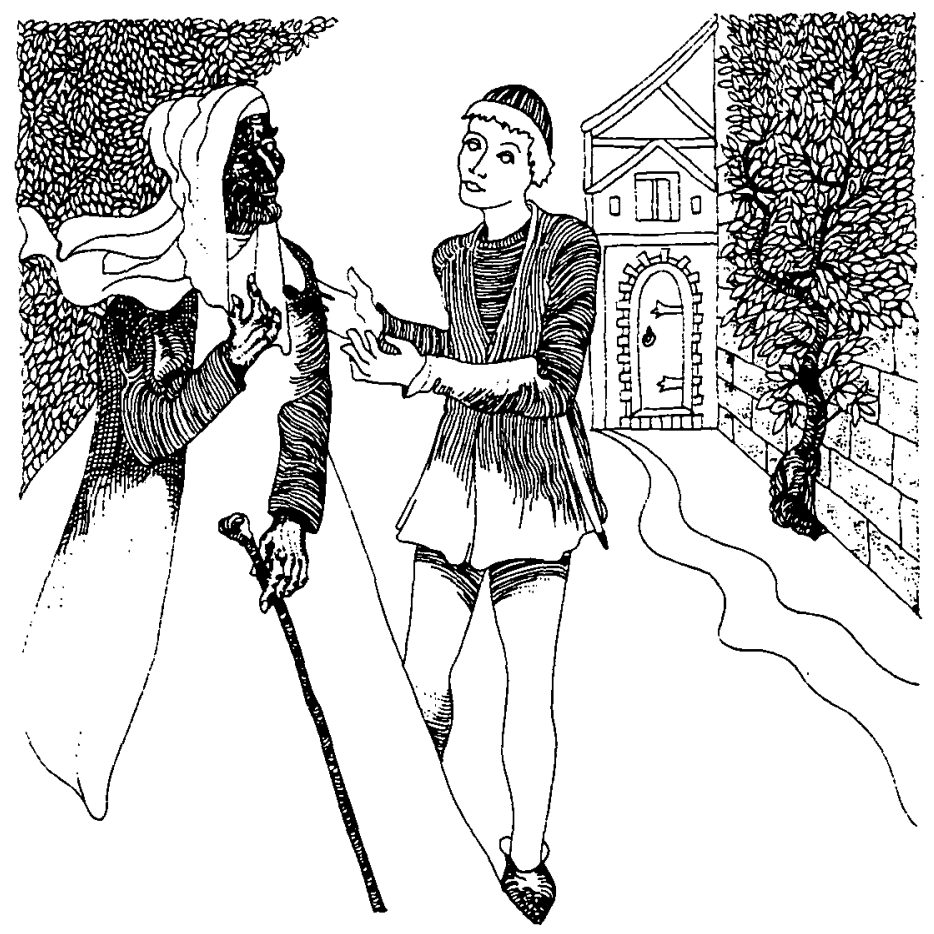

Sempronio and Celestina en route to Calisto's house, Act 1. Barcelona: Lumen, 1988. Illustration by Bartolomé Liarte 


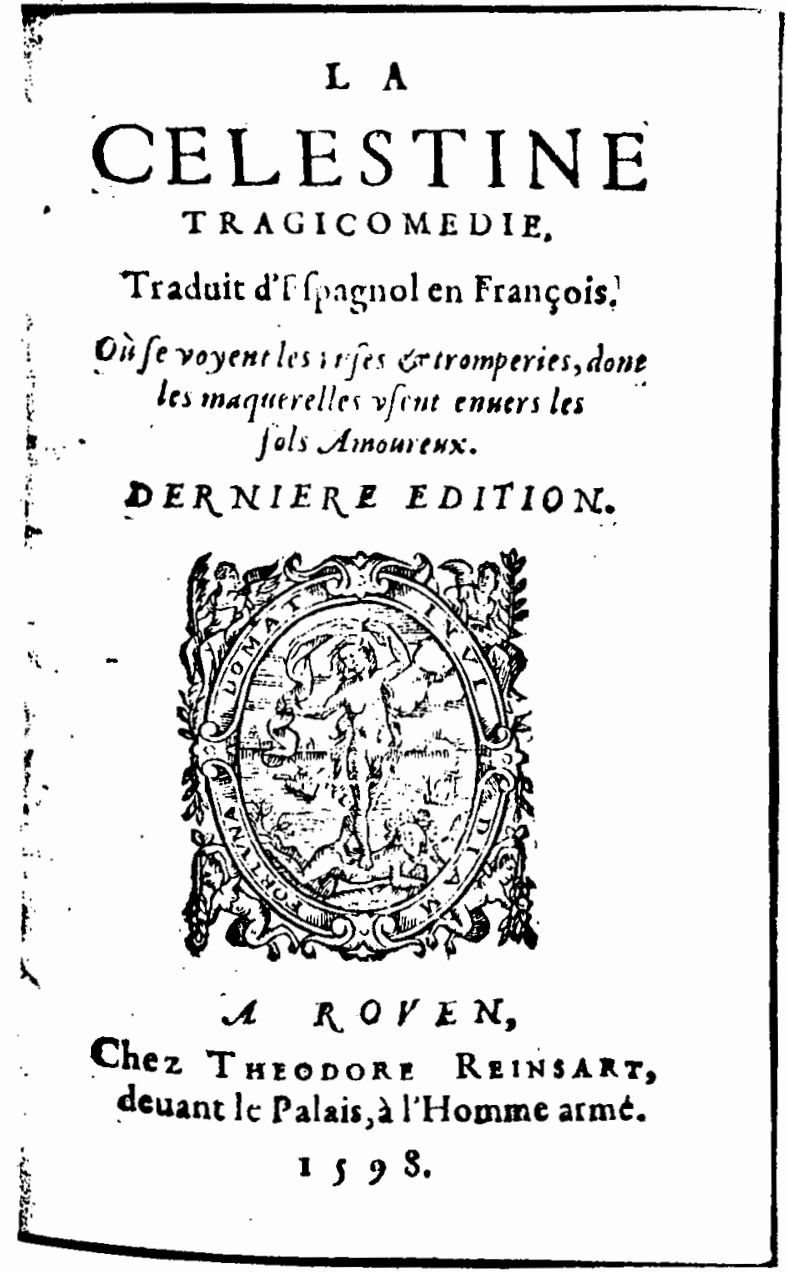

Title page. French translation, Rouen, 1598. Private collection of J. T. Snow 